\title{
Ayam Taliwang as a Solace After Disaster
}

\author{
Eli Jamilah Mihardja ${ }^{1,{ }^{*}}$, Tuti Widiastuti ${ }^{1}$, \\ Prima Mulyasari Agustini ${ }^{1}$, Fatin Adriati $^{2}$, B. P. K. Bintoro ${ }^{2}$ \\ ${ }^{I}$ Communication Program: Universitas Bakrie, Jakarta, Indonesia \\ 2Civil Engineering Program, Universitas Bakrie, Jakarta, Indonesia \\ "Corresponding author.Email: eli.mihardja@bakrie.ac.id
}

\begin{abstract}
Lombok tourism industry slumped dramatically since the earthquake. Comprehensive efforts are needed to make it rise again and bring prosperity to the people. Among them, through culinary.AyamTaliwang, despite coming from Sumbawa, a famous culinary carries the name of Lombok. However, the popularity of this cuisine is not managed well yet as the potential of culinary tourism. In fact, the potential of culinary tourism is an important element of destination marketing. This study uses data collected through e-observation and in-depth interviews with Lombok tourism stakeholders in Mataram in April 2019. As a result, there are various obstacles to involving culinary tourism within the framework of Lombok's tourism industry. Therefore, the results of this study are formulated suggestions to maximize the potential of culinary tourism as part of efforts to revive tourism in Lombok.
\end{abstract}

Keywords: destination branding, culinary, food tourism

\section{INTRODUCTION}

After the 2018 earthquake, Lombok tourism collapsed. The impact of the earthquake that struck the NTB region not only affected when the disaster occurred but until now the impact is still strongly felt by the community. Since the earthquake in Lombok almost a year ago, the condition of the tourism industry in West Nusa Tenggara (NTB ) still cause for concern. The occupancy rate of hotel rooms (occupancy) during February 2019 was only 32.63 percent, further down compared to the conditions in January 2019 which reached 32.84 percent.

In fact, the tourism sector is one of the mainstays of economic growth in NTB. (Tirto.id). the blow to the tourism sector was felt even when researchers were in the field to work on the measurement of heritage engineering (April 2019). The work will not get lighter when Lombok has passed the crisis period. The government, local residents, as well as tourism actors still have to reorganize the economy there - this arrangement can take years. That includes rebuilding the image of tourism and campaigning that Lombok is still the same as before the earthquake: a pleasant place, with friendly people, and food that chooses to compete (tirto.id)

West Nusa Tenggara is a province that has natural beauty that is so enchanting. NTB's natural charm is hunted by local and foreign tourists. However, it is not only natural charm that is a tourist destination, NTB also has a variety of impressive culinary. One of the famous culinary from NTB is Ayam taliwang (taliwang roast chicken).

Ayam taliwang is a food made from chicken that has been given a special Indonesian spice that is rich in spices and cooked by burning. Culinary, in this case, is Ayam taliwang, which has the potential to strengthen Lombok rebranding. Tag \#lombokbangkit on Instagram as well as the enthusiasm to rebuild Lombok should also include a revival of this type of culinary.

Ayam taliwang dishes are very popular everywhere. However, does Lombok itself become a culinary potential that can support the re-branding of Friendly Lombok? Therefore, this article is intended to explore the Ayam taliwang positioning in rebranding Lombok as a tourist destination.

\section{METHODS}

This research was conducted in April 2019 in Mataram and its surroundings. The approach used was descriptive qualitative. According to Denzin and Lincoln in the book Moleong states that Qualitative research is research that uses a natural setting, with the intention of interpreting phenomena that occur and are carried out by involving the sharing of existing methods. In this study the authors used the case study research method.

Case studies are research methods that use various data sources (as much as possible data) that can be used to research, describe, and comprehensively explain various aspects of individuals, groups, programs, organizations or events systematically (Kriyantono, 2010: 65). Robert K. Yin (2000: 18) limitated on the case study method as research that investigates phenomena in the context of real-life, when the boundaries between phenomena and contexts appear clearly, and where multiple sources are utilized. In this study, the type The case study used is an intrinsic case study in which research is carried out because of an interest or concern in a particular case. Thus, the qualitative method and instrument case study approach in this research are considered able to explain in more depth to find out the potential of culinary tourism, in this case, Ayam taliwang; to strengthen the branding of Lombok destinations after the earthquake 
disaster. Data collection is done by means of observation, interviews, and study documents.

Observation is the ability of a person to use his observations through the work of the five senses and assisted with the other five senses (Bungin, 2011: 118). Field observations were made in Mataram, North Lombok, West Lombok, and East Lombok. Interviews were conducted with NTB development and tourism stakeholders; including tourism industry, tourists, Mataram City government, and academics from Mataram State Islamic University. Document studies are carried out on government documents. Document studies are also carried out on posts about Ayam taliwang and \#lombokbangkit on Instagram social media.

The data analysis technique used in this study is an interactive model data analysis technique by Miles \& Huberman. In this model, there are four stages that must be done by researchers, namely data collection, data reduction, data display, and the stage of drawing conclusions or verification (Herdiansyah 2010: 164)

\section{RESULTS AND DISCUSSION}

Culinary tourism is very closely related to destination branding. Food as a form of destination identity (Lin, Pearson, \& Cai, 2011) and as a destination attraction (Horng, \& Tsai, 2012). Food tourism plays an important role in sustaining regional identity (Everett, \& Aitchison, 2008). Also, culinary tourism as a community development strategy (Green \& Dougherty, 2008) in the way likewise creative food clusters and rural development through place branding (Lee, Wall, \& Kovacs, 2015).

Gastronomy as a tourism resource (Sánchez-Cañizares, \& López-Guzmán, 2012) and also as destination branding in emerging markets (Williams,., Williams Jr., \& Omar, 2014). Baltescu (2016) stated that culinary experiences as a key tourism attraction. For example, Penang. Branding George Town world heritage site as a city of gastronomy as a prospects of creative cities strategy in Penang. (Suet Leng, \& Badarulzaman, 2014). Lombok can be endeavored to like Penang, previous studies show that Culinary can be used as a supporter of the local wisdom-based tourism industry in Lombok (Zahrulianingdyah, 2018) to support the prospect of OVOP-based halal tourism destinations (One Village One Product). (Lubis, 2018). The culinary industry has the potential to support Lombok's tourism policy to release dependence on Bali tourism towards international tourism (Karjaya, Mardialina, \& Hidayat, 2018).

For example, on Culinary tourism as a destination attraction: An empirical examination of destinations' food image. (Ab Karim, \& Chi, 2010). The potential of this image can be maximized on accounts on Instagram, for example. Observations and study of documents with the keyword 'chicken Taliwang' on Instagram produced posts about the Ayam taliwang which is generally located outside Lombok.

This finding has two implications. The presentation and promotion of the Ayam taliwang culinary in Lombok has not been well received. Lack of data regarding the Ayam taliwang culinary business in Lombok in particular and generally in NTB causes difficulties in choosing a destination when tourists actually visit Lombok. However, the popularity of Ayam taliwang outside its native area can be a promotional event. People will be curious to enjoy Ayam taliwang in its place of origin. Ayam taliwang will be the identity (Lin, Pearson, \& Cai, 2011) and attraction (Horng, \& Tsai, 2012) destinations. In accordance with the presentation of Everett \& Aitchison (2008), maximizing the Ayam taliwang's potential as food tourism can contribute to efforts to sustain regional identity. Ayam taliwang does not only belong to the NTB diaspora outside the region but also becomes the pride of its native region

Many [authentic flavors] that are irreplaceable are actually mBak. For example, Lombok kale is only delicious from Lombok. If in Java eating plecing with local kale will be different

Plecing is a kind of lettuce accompanying Ayam taliwang dish. It is believed, the large Lombok kale makes the vegetable taste soft and more crunchy than kale from other regions. What makes it different is the type of local chicken and spices used. Finally, how to cook and the atmosphere when dining will also make it unique. These points must be considered when making this culinary tourism specific marketing campaign strategy.

The development of the culinary industry is needed considering that gastronomy is one of the sources of the tourism industry (Sánchez-Cañizares, \& López-Guzmán, 2012). It is expected that the 2013 RIPPARDA projection regarding the potential of culinary tourism is carried in each target region. This is also related to the development of postearthquake Lombok tourism which tends to carry the Mandalika region because the area is relatively less affected. In the document, it states:

KSPDKuta Mandalika and its surroundings include the tourist areas of Gili Gede, Gili Anggu, Bangko-Bangko, Selong Blanak, Sade, Kuta, Gili Indah as a tourist area for beaches, underwater, marine-based sports, and culture.

The area that is now a priority for development does not specifically carry out culinary tourism. Therefore, corrections need to be made to immediately accommodate culinary tourism as a superior.

Culinary tourism as a community development strategy (Green \& Dougherty, 2008) in the way likewise creative food clusters and rural development through place branding (Lee, Wall, \& Kovacs, 2015). Previous research which mentioned that culinary tourism can be a strategy for developing local communities is a point of the effort to ensure citizens enjoy the 'cake' of development in tourism; not just as a spectator. Furthermore, culinary support for the tourism industry is based on local wisdom (Zahrulianingdyah, 2018). Among them, by making this culinary tour as, as revealed by Lubis (2018), Prospect of Ovop-Based Halal Tourism Destinations (One Village One Product)

The effective rebranding will attract investors and visitors (Bramwell and Rawding, 1996), attract government officials, generate civic pride (Williams, 1994), and prominently distinguish places from competing locations. The main steps in rebranding include the creation and registration of names, logo design and associated visual images, market research, internal communication, external public relations, and advertising (Haigh, 2000). More fundamentally, rebranding might be seen as a tactical problem where a new brand is operationally attached to placing a product, or as an important strategic issue where all urban processes of development authority revolve around the construction and development of new brands (Louro and Cunha, 2001). Manifestations of the strategic approach to rebranding are thought to include the development of shared vision and control that appear to be unrelated activities (Spaeth, 1998), systemic changes of the whole strategy in a direction according to new brand needs (Hedberg, 2001), and the use of integrated marketing communication ( namely ensuring that all agents involved in 
the rebranding process communicate the same message [Mazur, 2001]). Braune (2000) suggests that achieving these goals will be facilitated by the formation of a "round table" brand strategists, analysts and implementers (internal and external) "united from the start to share understanding and avoid going down to the" process mentality "'" (Braune 2000 : 399) That is important, Braune continues, so that the creators of the brand can empathize with the targets they reach.

According to Baker (2017), successful place branding takes a concerted effort to attain a vision where the reality is experienced by its customers matches the positive expectation or promise being conveyed by the city and its partners. In this case, rebranding Lombok as a safe and comfortable place to travel requires all efforts from all aspects of tourism, including culinary tourism. Ayam taliwang is one of the leading culinary dishes that is very well known outside of Lombok, but it is rarely exposed adequately as a local superior identity

\section{CONCLUSION}

This paper is an introduction to further studies on the potential of culinary tourism in the development of overall destination branding. In the case of Lombok which lost prestige safely and comfortably due to the earthquake disaster, culinary tourism is very feasible to be developed.

Ayam taliwang is a representative of culinary tourism potentials in Lombok. Disasters have taken place and every effort is made to recover and life must continue. As solace because of the disaster, Ayam taliwang really has the potential to be tourist excellence.

\section{ACKNOWLEDGMENT}

This research is funded by the Ministry of Research and Higher Education through the scheme of PDUPT for budget year 2018-2019; contract number Kopertis 32/AKM/MONOPNT/2019 and Universitas Bakrie 148/SPK/LPP-UB/III/2019.

\section{REFERENCES}

[1] Kriyantono, R. (2010). Teknik Praktis Riset Komunikasi Jakarta: Kencana Perdana Media Group.

[2] Yin, R. K. (2012). Case study methods.

[3] Bungin, B. M. (2011). Konstruksi sosial media massa: kekuatan pengaruh media massa, iklan televisi dan keputusan konsumen serta kritik terhadap Peter L. Berger \& Thomas Luckmann. Kencana.

[4] Herdiansyah, H. (2010). Metodologi penelitian kualitatif untuk ilmu-ilmu sosial.

[5] Lin, Y. C., Pearson, T. E., \&Cai, L. A. (2011). Food as a form of destination identity: A tourism destination brand perspective. Tourism and Hospitality Research, 11(1), 30-48.

[6] Horng, J. S., Liu, C. H., Chou, H. Y., \& Tsai, C. Y. (2012). Understanding the impact of culinary brand equity and destination familiarity on travel intentions. Tourism management, 33(4), 815-824.

[7] Everett, S., \& Aitchison, C. (2008). The role of food tourism in sustaining regional identity: A case study of Cornwall, South West England. Journal of sustainable tourism, 16(2), 150-167.
[8] Green, G. P., \& Dougherty, M. L. (2008).Localizing linkages for food and tourism: Culinary tourism as a community development strategy. Community Development, 39(3), 148-158

[9] Lee, A. H., Wall, G., \& Kovacs, J. F. (2015). Creative food clusters and rural development through place branding: Culinary tourism initiatives in Stratford and Muskoka, Ontario, Canada. Journal of rural studies, 39, 133-144

[10] Sánchez-Cañizares, S. M., \& López-Guzmán, T. (2012). Gastronomy as a tourism resource: profile of the culinary tourist. Current issues in tourism, 15(3), 229-245.)

[11] Williams, H. A., Williams Jr, R. L., \& Omar, M. (2014). Gastro-tourism as destination branding in emerging markets. International Journal of Leisure and Tourism Marketing, 4(1), 1-18.).

[12] Baltescu, C. A. (2016). Culinary experiences as a key tourism attraction. Case Study: Brasov County. Bulletin of the Transilvania University of Brasov.Economic Sciences.Series V, 9(2), 107.

[13] Suet Leng, K., \& Badarulzaman, N. (2014). Branding George Town world heritage site as city of gastronomy: prospects of creative cities strategy in Penang. International Journal of Culture, Tourism and Hospitality Research, 8(3), 322-332.).

[14] Zahrulianingdyah, A. (2018). Kuliner Sebagai Pendukung Industri Pariwisata Berbasis Kearifan Lokal. Teknobuga, 6(1), 1-9.)

[15] Lubis, M. Z. M. (2018). Prospek Destinasi Wisata Halal Berbasis Ovop (One Village One Product). Maqdis: Jurnal Kajian Ekonomi Islam, 3(1), 31-47

[16] Karjaya, L. P., Mardialina, M., \& Hidayat, A. (2018).Kebijakan Pariwisata Lombok untuk Melepaskan Ketergantungan Terhadap Pariwisata Bali Menuju Pariwisata Internasional. Transformasi Global, 3(2), 145-169

[17] Ab Karim, S., \& Chi, C. G. Q. (2010). Culinary tourism as a destination attraction: An empirical examination of destinations' food image. Journal of hospitality marketing \& management, 19(6), 531555.

[18] Lin, Y. C., Pearson, T. E., \&Cai, L. A. (2011). Food as a form of destination identity: A tourism destination brand perspective. Tourism and Hospitality Research, 11(1), 30-48

[19] Everett, S., \& Aitchison, C. (2008). The role of food tourism in sustaining regional identity: A case study of Cornwall, South West England. Journal of sustainable tourism, 16(2), 150-167.

[20] Bramwell, B., \& Rawding, L. (1996). Tourism marketing images of industrial cities. Annals of Tourism research, 23(1), 201-221.

[21] Williams, D. (1994). " Ad perpetuam rei memoriam": The Vargas Regime and Brazil's National Historical Patrimony, 1930-1945. LusoBrazilian Review, 45-75.

[22] Louro, M. J., \& Cunha, P. V. (2001). Brand management paradigms. Journal of marketing management, 17(7-8), 849-875. 
[23] Spaeth, T. 1998. "Fresh Faces for 1998: New Corporate Names and Logos," Across the Board, 35/2: 24-30.

[24] Haigh, D. 2000. "Walking Away from a \$3 Billion Brand", Accountancy Age, 14 September: 22-24

[25] Hedberg, A. 2001. "Brand New World", Marketing Week, 23/51: 34-36

[26] Mazur, L. 2001. "Room with a View," Marketing Business, June: 20-23.

[27] Braune, J. 2000. "Consumer Empowerment Creates a Shift in the Marketing Model", Journal of Brand Management, 7/6: 395-404

[28] Baker, B. (2007). Destination branding for small cities: The essentials for successful place branding. Destination Branding Book. 